specialists' training according to problems of social work; formation of innovative social sphere specialists' training on the basis of competence approach.

Practical significance of the research is that the studying of the history of formation and development of future social sphere specialists' training, critical understanding of social and pedagogical practice will help to avoid mistakes at the present stage of competence development of the specialist and to use all accumulated experience in the most creative way.

Keywords: future specialists in the social sphere, social work, social worker, social teacher, vocational training.

DOI: https://doi.org/10.31392/NZ-npu-143.2019.20

УДК 378.014.

ORCID 0000-0002-8099-1566

Плющ В. М.

\title{
САМОСТІЙНА РОБОТА ЯК ОДНА ІЗ ФОРМ САМООСВІТИ СТУДЕНТІВ
}

Проблема самоосвіти - ие одна з педагогічних проблем, яка не втрачає своєї актуальності. Адже согодні суспільству потрібна активна, мобільна особистість, що володіє умінням планувати і самостійно організовувати власну діяльність, адекватно оиінювати якість і рівень результатів власної роботи, розширювати освітній простір для вирішення поставлених завдань та иілей. Ці якості відображаються в інтегрованій характеристиці властивостей особистості, яка виявляється в потребі, готовності $і$ здатності до самостійної освітньої діяльності.

У статті проаналізовано основні підходи до визначення понять “самоосвіта” та “самостійна робота". Здійснено аналіз співвідношення окреслених понять, який показав, щуо це два складних види діяльності, які можуть бути пов'язані між собою або збігатися один з одним окремими компонентами, зсув ијих понять може привести до неправильного вибору форм, засобів і методів їх практичної реалізаиії. Самостійну роботу слід розглядати лише як необхідну складову прочесу самоосвіти, вона формує готовність до самоосвіти, створює основу для можливості здійснення безперервної освіти та постійного підвищення своєї кваліфікачії. Оскільки прочес самоосвіти відбувається під час самостійної роботи студентів, ми можемо відзначити, що самоосвіту можна вважати метою і результатом діяльності, а самостійну роботу - засобом досягнення результату. Наголошено, щяо в умовах сьогодення самостійна робота не забезпечує якісну реалізацію поставлених перед нею завдань оскільки має недостатню цілеспрямованість, проблемність, навчально-методичне і технічне забезпечення, слабку контрольованість, недостатню диференційованість і варіативність.

Ключові слова: освіта, самоосвіта, самостійна робота студентів.

Сьогодні суспільству потрібна активна, мобільна особистість, що володіє умінням планувати і самостійно організовувати власну діяльність, адекватно оцінювати якість і рівень результатів власної роботи, розширювати освітній простір для вирішення поставлених завдань та цілей. Ці якості відображаються в інтегрованій характеристиці властивостей особистості, яка виявляється в потребі, готовності і здатності до самостійної освітньої діяльності. Необхідно зазначити, що 
в теорії самоосвітньої діяльності існує кілька понять, які часто використовуються як синоніми, що іноді призводить до утруднення сприйняття інформації. Зокрема, в науковій педагогічній та психологічній літературі для позначення близьких за змістом явищ використовуються такі поняття, як самостійна робота, самостійна діяльність, самоосвітня діяльність і самоосвіта. Отже, проблема самоосвіти - це одна з педагогічних проблем, яка не втрачає своєї актуальності.

У наукових дослідженнях можна виділити декілька підходів до дослідження самоосвіти:

- в теорії неперервної професійної самоосвіти (Л. Д. Бодалєв. А. В. Костенікова, В. М. Турченко тощо);

- в системі підвищення кваліфікації та підготовки фахівців, як одна 3 найдинамічніших форм підвищення рівня спеціаліста (Ю.М Кулюткін, Г. С. Сухобська тощо);

- в соціологічних дослідженнях, як діяльність особистості або соціальної групи, що характеризується свободою вибору роботи, пов'язаної з підвищенням культурного, освітнього, професійного, наукового рівнів і спрямованої на задоволення іï духовних потреб та реалізацію потреб в соціалізації і самореалізації (Л. Ф. Колесніков, Є. О. Шукліна тощо);

- в педагогічній психології, як основна складова самовиховання, самовдосконалення, саморозвитку особистості (Є.І. Ісаєв, В.І. Слободчиков тощо).

Метою статті $€$ дослідження проблеми розвитку умінь самоосвіти та виявлення співвідношення між самоосвітою і самостійною роботою студентів.

У наукових дослідженнях по-різному тлумачать термін “самоосвіта” (табл. 1).

\section{Таблиця 1}

Трактування поняття “самоосвіта” в педагогічній літературі

\begin{tabular}{|l|l|}
\hline \multicolumn{1}{|c|}{ Автор } & \multicolumn{1}{|c|}{ 3міст поняття “самоосвіта” } \\
\hline $\begin{array}{l}\text { А. Я. Айзенберг, } \\
\text { В. П. Бондаренко, } \\
\text { А. К. Маркова }\end{array}$ & $\begin{array}{l}\text { як цілеспрямовану систематичну пізнавальну діяльність, } \\
\text { керовану самою особистістю }\end{array}$ \\
\hline Г. М. Коджаспирова & $\begin{array}{l}\text { як розумове і світоглядне самовиховання, в процесі якого } \\
\text { відбувається розвиток вміння самостійно організовувати свою } \\
\text { діяльність 3 метою оволодіння нових знань }\end{array}$ \\
\hline $\begin{array}{l}\text { Б. Ф. Райський, } \\
\text { Г. К. Селевко }\end{array}$ & як вищу форму задоволення пізнавальних потреб \\
\hline Г. С. Закіров & $\begin{array}{l}\text { як самостійний спрямований пошук знань в конкретній галузі } \\
\text { діяльнсті }\end{array}$ \\
\hline П. І. Підкасистий & як безперервний процес зростання і розвитку знань \\
\hline $\begin{array}{l}\text { Ю. С. Калугін, } \\
\text { М. Г. Кузьміна }\end{array}$ & $\begin{array}{l}\text { як засіб набуття знань, умінь і навичок, розвитку пізнавальних } \\
\text { сил і здібностей }\end{array}$ \\
\hline $\begin{array}{l}\text { В. П. Зінченко, } \\
\text { Б. Г. Мешеряков }\end{array}$ & $\begin{array}{l}\text { як самостійну роботу, що протікає під опосередкованим } \\
\text { керівництвом з боку викладача, за бажанням особистості, що } \\
\text { самостійно опановує знання }\end{array}$ \\
\hline
\end{tabular}

Незважаючи на різноманітність трактувань самоосвіти, автори визначають самоосвіту як пізнавальну діяльність. Таким чином, якщо аналізувати наведені вище трактування самоосвіти з погляду діяльнісного підходу, то можна 
відзначити, що багато хто з них відображають лише деякі сторони процесу самоосвіти. Найбільш повно відображає сутність самоосвіти, на нашу думку, визначення, згідно з яким самоосвіта визначається як спеціально організована, активна, саморегульована, систематична пізнавальна діяльність, спрямована на досягнення певних особистісно і суспільно значущих освітніх цілей: задоволення пізнавальних інтересів, загальнокультурних і професійних запитів, підвищення кваліфікації [3].

3 огляду на безліч визначень поняття, можна також відзначити деякі основні ознаки самоосвіти: відсутність управління, самостійний пошук, оволодіння і розширення знань, підвищений інтерес, подальший розвиток [4].

Самоосвіта нерозривно пов'язана з освітою: без освіти не може бути самоосвіти, і навпаки. При цьому освіта $€$ родовим щодо поняття самоосвіти. Актуальним $€$ поступове зміщення співвідношення "освіта - самоосвіта" до домінування останньої. Основною метою самоосвіти $€$ підвищення ефективності навчання, розширення знань і особистісне самовдосконалення, засноване на самоконтролі. Соціальне державне замовлення, що відображає реальні освітні потреби суспільства визначає мету самоосвітньої діяльності студента у закладах вищої освіти.

Перехід до самоосвіти пов'язаний з психологічними змінами: освіта шляхом самоосвіти підпорядковується цілям особистісного зростання і вдосконалення [1, с. 83].

На початковому етапі свого розвитку самоосвіта $є$ ситуативною, стихійною, неусвідомлюваною активністю. Вона має цілеспрямований, несистематичний характер і самим суб’єктом часто не контролюється. Таке пізнання нерідко характеризується відсутністю чіткої спрямованості на певний предмет або галузь знань.

На наступному етапі ця активність набуває зовнішньої детермінації виконується під дією зовнішніх чинників, зокрема, під впливом педагога і набуває деякої цілеспрямованості та систематичності. Така самоосвіта характеризується зовнішньою мотивацією, збуджується на вимогу педагога.

Надалі відбувається наростання цілеспрямованості самоосвітньої активності, процес пізнання стає повністю самостійним, тобто в ньому присутні самовпорядкованість і внутрішня детермінація, яка проявляється у внутрішній мотивації пізнавального процесу.

Загальні закономірності процесу самоосвіти, які допомагають усвідомити сутність прагнення до неї, сфрормульовані Б. Ф. Райським:

1. Прагнення до самоосвіти тісно пов'язане з моральним і розумовим розвитком людини.

2. Прагнення до самоосвіти зростає шляхом регулярної самоосвітньої діяльності в міру задоволення пізнавальних потреб і інтересів студента.

3. Прагнення до самоосвіти залежить від рівня умінь самоосвіти і, в свою чергу, стимулює їх вдосконалення.

4. Прагнення до самоосвіти залежить від умов пізнавальної діяльності. Виникнення непереборних труднощів в задоволенні пізнавальних потреб і інтересів, а також переривання самоосвітньої діяльності тягне загасання прагнення до самоосвіти [6, с. 10-14].

Провідною формою організації навчального процесу в закладах вищої освіти є 
самостійна робота (більше 50\% часу), яка сприяє формуванню у студента готовності до самоосвіти, виховує пізнавальні та професійні інтереси, розвиває мотивацію навчання, сприяє зростанню творчої активності та ініціативи [5]. Різні трактування цього поняття наведено в табл. 2.

Згідно з наведеними визначеннями, самостійна робота, з одного боку, трактується як вид діяльності, що спонукає активність, пізнавальний інтерес, самостійність, і як основа самоосвітньої діяльності, спонукання до подальшого підвищення кваліфікації, а з другого боку, як система заходів або педагогічних умов, що забезпечують керівництво самостійною діяльністю студентів.

Загалом самоосвіту можна трактувати, з одного боку, як різновид самостійної діяльності, пов'язану з підвищенням рівня освіченості, оволодінням новими знаннями, вдосконаленням практичних професійних умінь. 3 другого боку, необхідно враховувати, що поняття “самоосвіта" більш ширше за поняття "самостійна робота", і в широкому сенсі цілком спирається на творчість, особисту ініціативу.

Таблиця 2

Трактування поняття “самостійна робота" в педагогічній літературі

\begin{tabular}{|c|c|}
\hline Aвmор & Зміст поняття “самостійна робота" \\
\hline Г. М. Коджаспірова & $\begin{array}{l}\text { засіб, що формує пізнавальні здібності учнів, їх спрямованість } \\
\text { на безперервну самоосвіту }\end{array}$ \\
\hline $\begin{array}{l}\text { Б. П. Есипов, } \\
\text { В. А. Сластенин } \\
\text { А. В. Усова }\end{array}$ & $\begin{array}{l}\text { це активна пізнавальна діяльність учнів, яка виконується без } \\
\text { особистої участі викладача, але за його завданням і в спеціально } \\
\text { відведений час }\end{array}$ \\
\hline П. І. Підкасистий & $\begin{array}{l}\text { це процес залучення учнів до самостійної пізнавальної } \\
\text { діяльності, засіб її логічної і психологічної організації }\end{array}$ \\
\hline Л. Г. Вяткин & $\begin{array}{l}\text { така діяльність, яка в умовах систематичного зменшення прямої } \\
\text { допомоги викладача дає змогу виконувати навчальні заняття з } \\
\text { метою свідомого і міцного засвоєння знань, умінь і навичок } \\
\text { розвитку пізнавальної самостійності як риса особистості того, } \\
\text { хто навчається }\end{array}$ \\
\hline Б. Г. Иоганзен & $\begin{array}{l}\text { сукупність дій, спрямованих на виховання самостійності та } \\
\text { активності як рис особистості з формування умінь раціонально } \\
\text { оволодівати корисною інформацію. }\end{array}$ \\
\hline
\end{tabular}

Самостійну роботу виправдано розглядати як засіб залучення студентів до самостійної пізнавальної діяльності. Чітко сформульовані в кожному конкретному типі і вигляді самостійної роботи завдання нададуть можливість залучити студентів до керованої пізнавальної діяльності.

Аналіз процесу самоосвіти та самостійної роботи особистості показав, що це два складних види діяльності людини, які можуть бути пов'язані між собою або збігатися окремими компонентами. Зсув цих понять може привести до неправильного вибору форм, засобів і методів їх практичної реалізації. Самостійну роботу, на наш погляд, слід розглядати лише як необхідну складову процесу самоосвіти, що має більш широкі цілі. Самоосвіта на відміну від самостійної роботи - це не тільки діяльність, спрямована на засвоєння, поглиблення і оволодіння нових знань в період навчання у закладах вищої освіти, 
а й фрорма продовження навчання молодих фахівців після його закінчення.

Вирішуючи питання вдосконалення управління самоосвітою студентів важливо дотримуватися вибору відповідної стратегії, в основі якої знаходиться ідея доцільної управлінської взаємодії між викладачами і студентами в цілісному педагогічному процесі. Спираючись на самоврядування студентів, на їхню ініціативу і ділові якості, на творчу активність і готовність до самоврядування доцільно прагнути до поступового переходу всієї самостійної роботи студентів до самоосвіти [2].

Таким чином, головна відмінність самостійної роботи від самоосвіти полягає в тому, що самостійна робота студентів, головним чином, спрямована на засвоєння певних знань, умінь, способів діяльності, передбачених змістом освітніх програм і складає основу підготовки фахівця. А самоосвіта студента - це добровільна діяльність, націлена на оволодіння знаннями під час самостійної роботи без детального керівництва з боку викладача, яка неможлива, якщо у студентів не сформовані початковий досвід пізнавальної діяльності, потреба до неї і емоційно-вольові якості.

Оскільки процес самоосвіти відбувається під час самостійної роботи студентів, ми можемо відзначити, що самоосвіту можна вважати метою і результатом діяльності, а самостійну роботу - засобом досягнення результату. Варто зазначити, що самостійна робота через недостатню цілеспрямованість, проблемність, навчально-методичну і технічну забезпеченість, слабку контрольованість викладачів, недостатню диференціацію і варіативність, при якій мінімально враховуються індивідуальні можливості, потреби і інтереси студента, не може забезпечити якісну реалізацію поставлених перед нею завдань. Тому подальші дослідження будуть спрямовані на удосконалення процесу організації самостійної роботи студентів.

\section{Використана література:}

1. Булдаков С. К. Образование: цели, идеи, методология. Опыт философского исследования. Кострома : Изд-во КГУ Н. А. Некрасова, 2000. 180 с.

2. Вербицкий А. А. Активное обучение в высшей школе: контекстный поход. Москва: Высшая школа, 1991. 208 с.

3. Коджаспирова Г. М. Культура прфессионального самообразования педагога : пособие / под ред. Ю. М. Забродина. Москва : Академия, 1994. 344 с.

4. Кузьмина М. Г. К вопросу о понятии “самообразование”. Формирование у учащихся стремления к образованию. Волгоград : Изд-во ВГПИ, 1976. С. 43-49.

5. Локота О. В., Давтян М. Г. Самостоятельная работа студентов : методические рекомендации. Ростов н/Д. : Изд-во СКАГС, 2010. 45 с.

6. Райский Б. Ф. О некоторых закономрностях процесса самообразования. Формирование $у$ учащихся стремления к самообразованию. Волгоград, 1976. С. 10-15.

\section{References:}

[1] Buldakov S. K. (2000). Obrazovanie: celi, idei, metodologiya. Opyt filosofskogo issledovaniya. Kostroma : Izd-vo KGU N. A. Nekrasova. $180 \mathrm{~s}$.

[2] Verbickij A. A. (1991). Aktivnoe obuchenie v vysshej shkole: kontekstnyj pohod. Moskva: Vysshaya shkola. $208 \mathrm{~s}$.

[3] Kodzhaspirova G. M. (1994). Kultura prfessionalnogo samoobrazovaniya pedagoga: posobie / pod red. Yu. M. Zabrodina. Moskva : Akademiya. 344 s. 
[4] Kuzmina M. G. (1976). K voprosu o ponyatii "samoobrazovanie". Formirovanie u uchashihsya stremleniya k obrazovaniyu. Volgograd : Izd-vo VGPI. S. 43-49.

[5] Lokota O. V., Davtyan M. G. (2010). Samostoyatelnaya rabota studentov : metodicheskie rekomendacii. Rostov n/D. : Izd-vo SKAGS. 45 s.

[6] Rajskij B.F. (1976). O nekotoryh zakonomrnostyah processa samoobrazovaniya. Formirovanie $u$ uchashihsya stremleniya $k$ samoobrazovaniyu. Volgograd. S. 10-15.

\section{ПлюЩ В. М. Самостоятельная работа как одна из форм самообразования студентов.}

Проблема самообразования - это одна из педагогических проблем, которая не теряет своей актуальности. Ведь сегодня обществу нужна активная, мобильная личность, которая владеет умением планировать и самостоятельно организовывать собственную деятельность, адекватно оченивать качество и уровень результатов собственной работы, расширять образовательное пространство для решения поставленных задач и иелей. Эти качества отображаются в интегрированной характеристике свойств личности, которая выявляется в потребности, готовности и способности к самостоятельной образовательной деятельности.

$B$ статье проанализированы основные подходы $\kappa$ определению понятий “самообразование" и “самостоятельная работа". Осуществлен анализ соотномения определенных понятий, который показал, что это два сложных вида деятельности, которые могут быть связаны между собой или совпадать друг с другом отдельными компонентами, смещение этих понятий может привести к неправильному выбору форм, средств и методов их практической реализации. Самостоятельную работу следует рассматривать лишь как необходимое составляющую процесса самообразования, она формирует готовность к самообразованию, создает основу для возможности осуществления непрерывного образования и постоянного повышения своей квалификаиии. Поскольку прочесс самообразования происходит во время самостоятельной работы студентов, мы можем отметить, что самообразование можно считать целью и результатом деятельности, а самостоятельную работу - средством достижения результата. Отмечено, что в сегодняшних условиях самостоятельная работа не обеспечивает качественную реализацию постеленных перед ней задач поскольку имеет недостаточную целеустремленность, проблемность, учебнометодическое и техническое забезпеченя, слабую степень контроля, недостаточную дифференцированность и вариативность.

Ключевые слова: образование; самообразование; самостоятельная работа студентов.

\section{PLUSCH V. M. Independent work as one of the forms of student self-study.}

The problem of self-education is one of the pedagogical problems that does not lose its relevance. After all, society needs an active, mobile personality with the ability to plan and organize their own activities, to adequately assess the quality and level of results of their own work, to expand the educational space to meet their goals and objectives. These qualities are reflected in the integrated characteristics of personality traits, which is manifested in the need, willingness and ability for independent educational activity.

The article analyzes the main approaches to defining the concepts of self-study and independent work. It also considers the connection between the above-mentioned concepts. Thus, it is found that these two complex types of human activity, which may be related to each other or coincide with each other. However, the shift in these concepts may lead to choosing incorrect forms, means and methods of their practical implementation. Independent work should be viewed only as a necessary component of self-study since it forms the readiness for self-study and creates the basis for continuing education and continuing professional development. Given that the process of self-study occurs during independent work of students, one can note that self-study can be regarded as a goal and result of activity, whereas independent work is seen a means to achieve the result. It is pointed out that under today's conditions independent work does not properly fulfil the tasks it should since it lacks purposefulness, focus on problem-solving, educational and methodological and technical support, is poorly monitored, insufficiently differentiated and variable.

Keywords: education; self-education; students' independent work; self-cognition. 